“Fuzzy front end" practices in innovating Japanese companies

Prof. Dr. Cornelius Herstatt

Dipl.-Ing. Birgit Verworn

Dipl.-Kfm. Christoph Stockstrom

Prof. Dr. Akio Nagahira

Osamu Takahashi

Juni 2004

Arbeitspapier Nr. 25 


\title{
"Fuzzy front end" practices in innovating Japanese companies
}

\author{
Cornelius Herstatt ${ }^{1}$, Birgit Verworn ${ }^{2}$, Christoph \\ Stockstrom $^{3}$, Akio Nagahira ${ }^{4}$ and Osamu Takahashi ${ }^{5}$
}

\author{
${ }^{1}$ c.herstatt@tu-harburg.de \\ birgit@verworn.com \\ ${ }^{3}$ stockstrom@tu-harburg.de \\ 4akio.nagahira@most.tohoku.ac.jp \\ 5osamu.takahashi@most.tohoku.ac.jp \\ 1,2,3 Institute for Technology and Innovation Management, Technical University Hamburg-Harburg, \\ Schwarzenbergstrasse 95, D-21073 Hamburg, Germany \\ ${ }^{4,5}$ Graduate School of Engineering, Tohoku University, Sendai, Japan
}

\begin{abstract}
In this paper, we report on the results of a large-scale study about typical front-end-related innovation practices in 553 Japanese mechanical and electrical engineering companies. We explore typical activities concerning the generation and assessment of new product ideas, the reduction of technological as well as market uncertainty and front end planning. Finally, we report on differences between successful and unsuccessful companies.

Our study confirms earlier findings about the frequent use of creativity techniques in Japan during the process of idea generation. We also find companies to intensively involve upper management and customers into NPD projects. While integrating upper management is of vital importance for assessing new product ideas, integrating customers and users is primarily used to developing product ideas and concepts .

We further find evidence that successful companies integrate their customers more frequently in the process of developing and assessing new product ideas than non successful companies. In addition, the former integrate customer requirements into their product definitions more often and also translate these requirements into technical specifications more frequently than non-successful companies. Finally, successful companies more often systematically plan a project prior to its start than unsuccessful ones.
\end{abstract}

\section{Introduction}

In a comparison of 14 German and 14 Japanese NPD projects, Herstatt et al. (2004: 20) report on front-end related activities in these countries. They found Japanese companies to rely on a comparatively formal approach with strong methodological support to reduce uncertainty. With this paper we try to extend and test their propositions in order to develop a deeper understanding of Japanese front end activities in the context of a large scale study. We will report on findings about typical activities such as idea generation and assessment, and the reduction of market and technological uncertainty. In addition, we will show differences in the practices between successful and unsuccessful companies with regard to the execution of several front end activities.

For this purpose, the paper is organized as follows: Part 2 provides an overview of our study describing our sample and addressing methodological issues. We present our findings concerning typical front-endrelated activities in part 3 . Next, we report on the differences between successful and unsuccessful companies. This paper ends with a discussion of our results and suggestions for further research. 


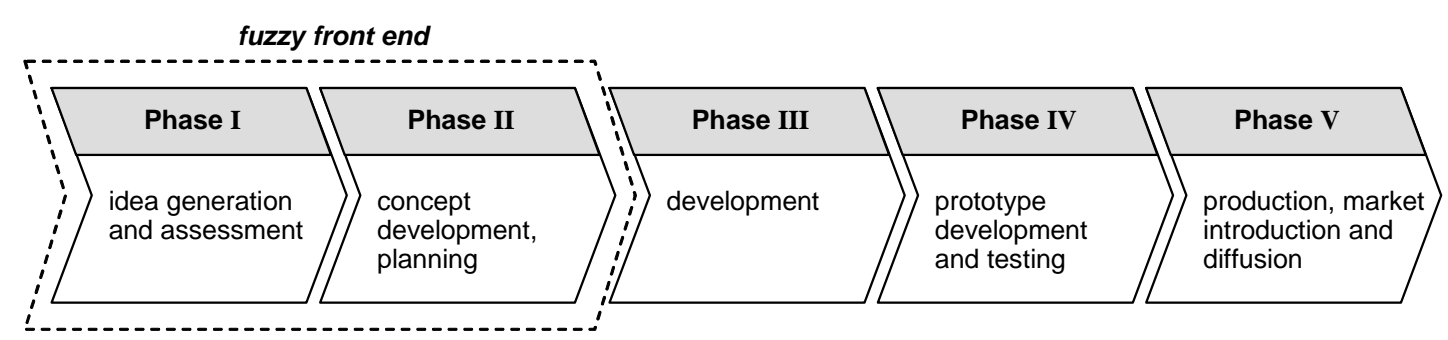

Figure 1. The new product development process. (Source: Herstatt and Verworn, 2004: 437)

\section{Study}

\section{Aim of the study}

Empirical work by Cooper and Kleinschmidt showed that "the greatest differences between winners and losers were found in the quality of execution of predevelopment activities" (Cooper and Kleinschmidt, 1994: 26). Two factors were identified as playing a major role in product success: the quality of executing the pre-development activities, and a well defined product and project prior to the development phase (Cooper and Kleinschmidt, 1990: 27).

A study of 788 new product launches in Japan confirmed that Japanese new product professionals view the importance of pre-development proficiency in much the same way as their American and European counterparts (Song and Parry, 1996: 422, 433).

Beside this acknowledged relevance of the fuzzy front end, most of existing studies do not look in any greater detail into the various distinct activities within the frame of the fuzzy front end and present them collectively under the heading "pre-development activities". This study tries to develop a deeper understanding of fuzzy front end practices in Japanese companies as well as innovation projects. Which methods, tools, and approaches are used? Which techniques support the important task to reduce project uncertainties, e. g. related to market or technology? How do successful companies approach the fuzzy front end of innovation compared to less successful or unsuccessful companies? These are the questions we will take a closer look at.

\section{Methodology}

We reviewed literature about front-end activities (e.g., Khurana and Rosenthal, 1998; Koen, Ajamian and Burkart, 2001; Kim and Wilemon, 2002; Rubinstein, 1994; Verganti, 1997; Zhang and Doll, 2001) and developed a standardized questionnaire to assess front end related activities in Japanese companies. Figure 1 shows our frame of the fuzzy front end phase within a model of the new product development process.

In Japan, the interpretation of the questions was verified during exploratory interviews and a mailed pre-test. For the large-scale study, we identified a total of 2000 mechanical and electrical engineering companies. MOST (Management of Science and Technology Department) at the Tohoku University in Sendai send the questionnaire to the R\&D directors of these companies. 553 companies finally answered the questionnaires (response rate $=28 \%$ ).

\section{Sample}

The Sample contains companies ranging in size from below 50 employees to large corporations, one of which has more than 100,000 employees. The structure of our sample is further reflected in annual sales which vary between 5 million and 31.1 trillion Yen. Therefore the majority of the sample consists of medium to large companies employing with 100 to 10,000 employees and annual sales between 1 billion and 1 trillion Yen.

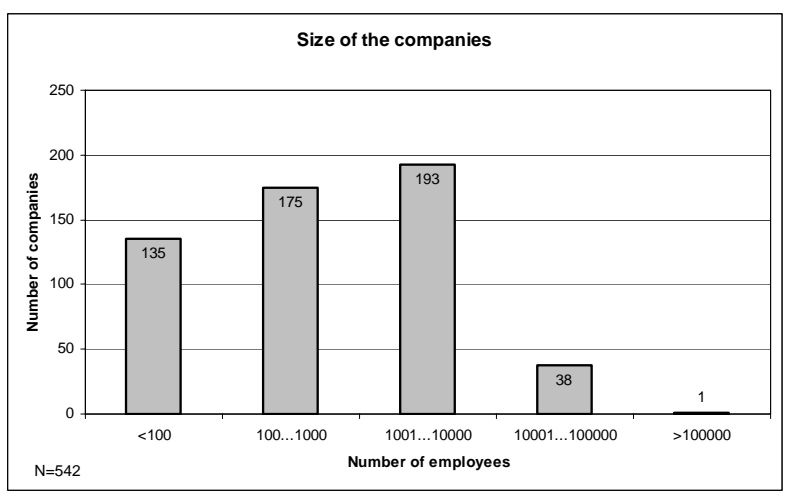

Figure 2. Size of the companies.

\section{Company Success:}

Company success was measured by two items: The achievement of corporate profitability and growth goals during the last five years. In doing so, we follow the notion of evaluating success by comparing the actual outcome of the companies' activities with the organizations' planned objectives (Zhang and Doll, 2001: 102). While this approach may be criticized for not generating standardized measures of success and failure across firms, this rather reflects an artifact of real-world differences between firms, industries, economic conditions, accounting rules, temporal situations, and decision criteria rather than a criticism of these scales (Song and Parry, 1997: 7). 
Reflecting Japan's difficult economic state (Yoshida, 2002: 2), it was not surprising that $47 \%$ of the companies stated that they did not meet expected profitability goals during the last five years. In addition, $50 \%$ of the companies stated that corporate growth remained below expectations during the same time.

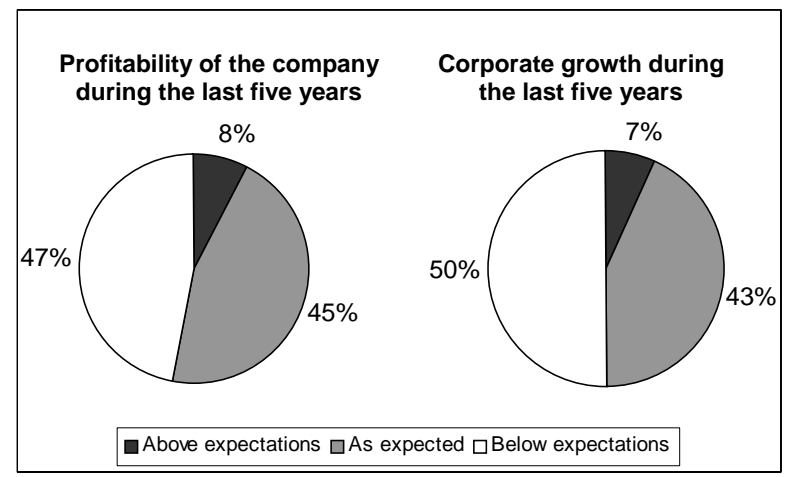

Figure 3. Corporate Success.

In order to be categorized as successful, companies had to meet or exceed their corporate goals on both of the aforementioned items, while companies which did not meet either goal were considered to be unsuccessful for the purpose of our analysis. Companies which achieved one of these goals but failed concerning the other were not included into the analysis in part 5 . Overall, 238 companies were labeled successful, while 225 companies were unsuccessful.

\section{Results}

This section summarizes our key findings about fuzzy front end practices in the Japanese companies. Firstly, we will describe how ideas were typically generated, assessed, and selected. Secondly, we will summarize how market and technological uncertainty were reduced prior to project execution. Finally, we will describe typical project planning activities as a further opportunity to reduce project related uncertainties and as a basis of controlling during the following steps of the product development process.

\section{Idea generation}

$27 \%$ of the companies engage in a systematic search for new product ideas. When this is the case, ideas are primarily sought internally. Only a small minority of companies additionally looks for ideas outside of the firm. None of the respondents searched for new product ideas exclusively outside of his company. Clear responsibilities are standard: almost every firm assigns the search for new product ideas to an individual or a group. However, only about a third of the respondents use databases to store and process new product ideas.

Our present study corresponds with former findings about the frequent use of brainstorming in Japan (Harryson, 1996: 26): Close to 60\% of the companies regularly apply brainstorming to develop new products.
Only the use of kaizen, which is also employed by $60 \%$ of the companies, is equally widespread. While value analysis is still applied by $44 \%$ of the participants, only $11 \%$ of the companies report the use of other creativity techniques, which therefore seem to play a minor role. While answers showed a wide variety of different practices, a frequently mentioned instrument is an employee proposal system usually connected to a reward scheme.

\section{Idea assessment}

$54 \%$ of the companies have their ideas assessed by individuals as well as by groups. The minority of the companies employs only one of these two possibilities: $26 \%$ only let groups assess their ideas, while $20 \%$ rely on assessments by individuals.

In $99 \%$ of the companies, upper management is at least sometimes involved in the idea assessment, for $78 \%$ of the companies, this is a typical procedure.

Following the aforementioned notion of reducing as much uncertainty as possible by employing interdisciplinary teams for idea assessment, $46 \%$ of the companies frequently use multifunctional groups. Another 34\% at least sometimes do so. However, 20\% of the companies do not consider this to be necessary. Out of the 440 companies which at least sometimes use interdisciplinary teams to assess new product ideas more than $60 \%$ involve the $\mathrm{R} \& \mathrm{D}$ department in this process. The marketing department is employed by more than half of the companies. $20 \%$ have the after sales or customer service department participate in the assessment, while $12 \%$ include other functions.

$28 \%$ of the participants stated that they generally use technical criteria to assess new product ideas. Another $32 \%$ sometimes include technical criteria in their consideration. The remaining $40 \%$ do not bear these in mind during their evaluation process. Regarding the nature of these technical criteria, the 329 firms which at least sometimes employ them mainly consider technical feasibility (78\%). The availability of the required technology inside the firm is a criterion used by $48 \%$ of these 329 respondents.

$45 \%$ of all companies frequently assign weights to economic and technical criteria in accordance with their importance. Another 29\% sometimes resort to scoring the various criteria.

\section{Reduction of market uncertainty prior to development}

We found that $53 \%$ of the participating firms contact their customers very often. Another $41 \%$ at least sometimes contact their users to develop or evaluate new product ideas. Despite the important role of customers in the new product development process, especially with regard to the reduction of market uncertainty, $6 \%$ of the companies only very seldom contact their customers for this purpose.

When customers are contacted, this is most often done by the marketing department (48\%) and/or the R\&D department (47\%). Other functions such as 


\section{According to which criteria do you select customers/users you contact to develop and evaluate new ideas?}

Degree of dissatisfaction with existing product

Motivation to solve the problem with existing product Knowledge of the customer about technology incorporated in potential product

Importance of customer (e.g. sales volume)

Good relationship with the customer (e.g. with regard to secrecy)

Other

No criteria are used

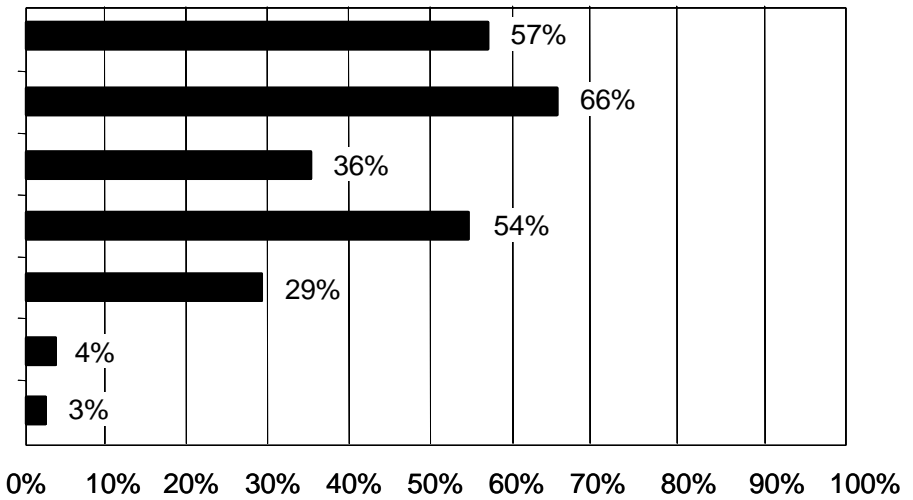

$\mathrm{N}=551$ Percentage of companies

Figure 4. Criteria for customer selection.

application engineering (14\%) and after sales/customer service $(13 \%)$ play a minor role.

Customers can be selected according to different criteria and motivations. Depending on which criteria the selection process is based on, the integration of users may be more or less beneficial. Figure 4 summarizes our results:

The factors representing drivers for participation in the NPD process on behalf of the customer seem to be most important: The motivation of the customer to solve his problem he has with the existing technology is the most important criterion and is applied by $66 \%$ of the companies. In addition, the degree of dissatisfaction with the existing product plays an important role, as this criterion is used by $56 \%$ of the respondents. In contrast to this, the following criteria rather consider benefits on behalf of the companies: For $54 \%$ of the firms, the importance - in terms of e.g. sales volume of the customer is a criterion for asking him to participate in the NPD process. 36\% hope to benefit from the customer's knowledge about the technology incorporated in the new product and select them accordingly. A good relationship with the customer is a selection criterion for $29 \%$ of the respondents. Among the diverse other criteria for selecting users to develop and evaluate new product ideas, two themes stick out: Some companies randomly select their users to participate - thereby employing no criteria. Besides, some companies ask users of a current product to participate - regardless of whether they are their own or customers of a competitor. In only one case the company specifically searched for competitors' customers to advice them in the development and evaluation of new product ideas.

Direct customer contact represents the most often used market-related source of information. For other means to acquire knowledge about the target market see Figure 5. As has been described by Harryson (1996: 61), Japanese companies put a strong emphasis on analysing competitive products. We find support for these findings, as $78 \%$ of the companies acquire information this way. Customer complaints also play an important role. They are analyzed by $72 \%$ of the firms. In contrast to this, only half of the respondents conduct customer surveys and $46 \%$ rely on studies and market research carried out by third parties. Other marketrelated sources of information only play a minor role.

Considering the importance of the customer as a source of information, it is surprising to see that only $27 \%$ of the companies very often systematically integrate customer requirements into the definition of their new product concepts. This may be due to the fact that it is sometimes hard for users to specifically articulate their needs and functional fixedness may hinder them to imagine the requirements they want future products to meet (Herstatt, 2002: 71; Mullins and Sutherland, 1998: 228). Consequently, 53\% of the firms just sometimes integrate customer requirements and $20 \%$ even only very seldom.

Systematically translating the customer requirements into technical specifications allows the companies to incorporate the information into their product concepts. This step is at least sometimes carried out by $85 \%$ of the firms. While $15 \%$ refrain from any translation of customer requirements into technical specifications, $39 \%$ systematically do so. A well-known tool for this translation is QFD (Quality Function Deployment). For an overview of this technique see Griffin and Hauser (1993).

\section{Reduction of technical uncertainty prior to development}

There is a variety of different tools and methods which allow for the reduction of technical uncertainty during the pre-development phase. One way to reduce technical uncertainty is to evaluate technical feasibility with early prototypes. This could be either based on virtual prototypes, rapid prototypes or early, rough physical prototypes. In addition to showing technical feasibility, such early prototypes can be used for improving the communication within the development team, with customers or with top management. It enables an early assessment of customers' needs and enhances top management support e.g. for the commitment of resources (Clayton et al., 1996: 449; Watts et al. 1998: 48pp.). 


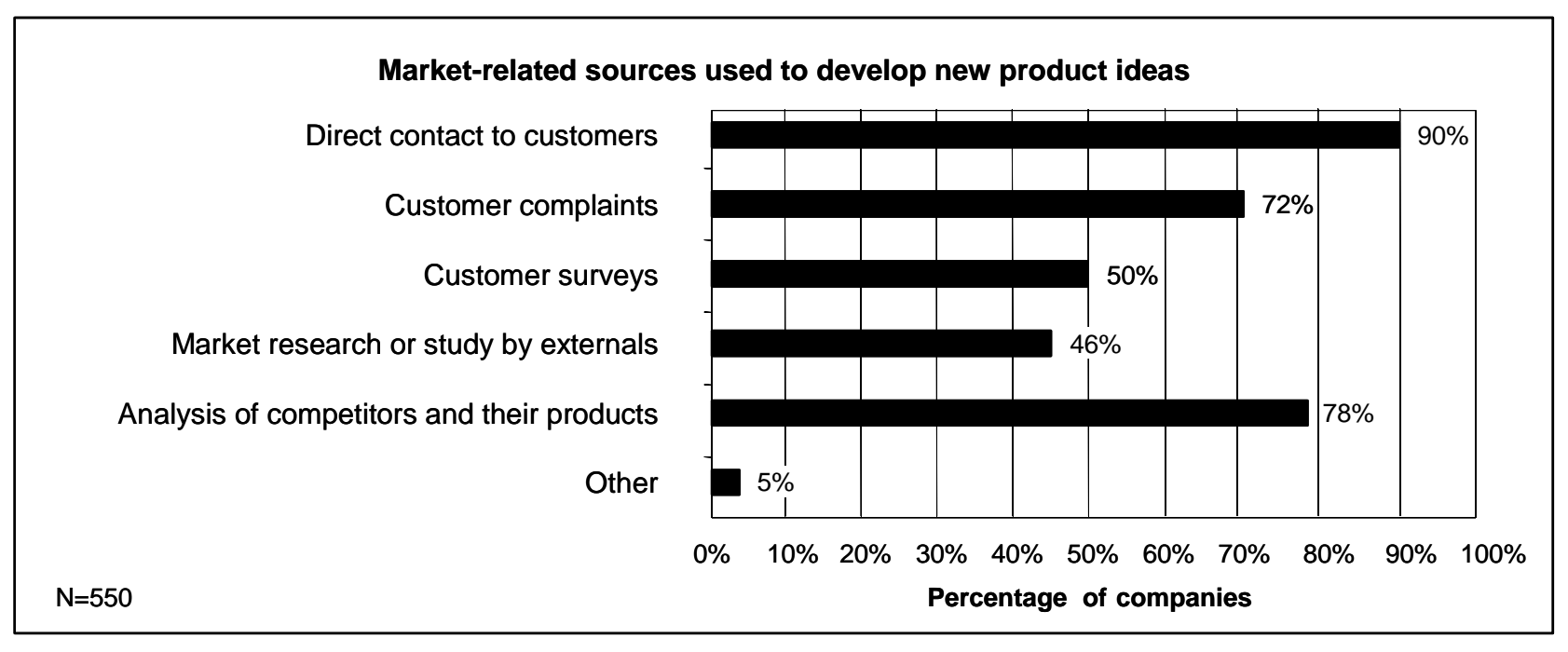

Figure 5. Market-related sources used to develop new product ideas.

In our study, almost $90 \%$ of the companies make use of early physical prototypes, $15 \%$ apply rapid prototyping and $11 \%$ use virtual prototyping (see Figure 6). Almost half of the companies use simulation to reduce technical uncertainty. Overall, only $5 \%$ of the respondents do not apply any methods or tool to reduce technical uncertainty during the predevelopment phase. This supports the proposition that Japanese companies rely on a strong methodological support to reduce uncertainty (Herstatt et al., 2004).

\section{Front end project planning}

For $40 \%$ of the respondents, a systematic initial planning is a standard procedure. $49 \%$ at least sometimes plan their projects systematically. $11 \%$ do not engage in systematic initial planning at all. In the next section, we evaluate the effect of systematic initial planning on success. In this section, we look at the different planning activities and support of these activities by methods and tools in more detail.

In our study, almost half of the companies define milestones with deliverables (see Figure 7). Terms like work packages are not widespread in Japan. Instead, projects are broken down into "teams". Cost plans are assigned to these teams. This is the case in $64 \%$ of the companies we looked at. In addition, more than half of the companies determine the required staff for the project already during the initial planning. With regard to tools, bar charts, network diagrams and project management software are not often used $(18 \%, 3 \%$, $14 \%$ of the companies). This is in line with former results (Herstatt et al., 2004).

In sum, the descriptive results about fuzzy front end practices in the Japanese companies we looked at confirm a rather systematic approach to the front end with strong methodological support. In the next section, we will look at the effect that different front end practices have on companies' success.

\section{Comparing successful and unsuccessful companies}

In this section, we compare successful and unsuccessful companies with regard to different front-end-related activities that we argue to be influential on NPD success. We do so with the help of contingency tables which classify the companies by the achievement of their corporate growth and profitability goals on the one hand and by the execution of the respective activity on the other.

The product development process starts with an idea originating from basic research, customer based techniques, or creativity techniques (Cooper and Kleinschmidt, 1990: 45). Not only may ideas stem from a variety of sources, also their generation often is a complex and creative task associated with considerable uncertainty. While researchers argue about whether to have individuals generate ideas (Rochford, 1991: 289) or to leave this task to - preferably multidisciplinary teams (Baker, Green and Bean, 1985: 40; Geschka, 1992: 284, 294-296; Rubinstein, 1994: 656; Rochford, 1991: 289; Song and Parry, 1997: 9), a systematic approach to this endeavour is likely to contribute to the reduction of uncertainty and thereby positively influences success. Hence, we conjecture that

P1: Companies engaging in a systematic search for new product ideas are more successful than companies which do not search systematically for new product ideas.

\begin{tabular}{l|c|c|c}
\hline \multirow{2}{*}{$\begin{array}{c}\text { Systematic } \\
\text { search }\end{array}$} & \multicolumn{2}{|c|}{ Success } & \multirow{2}{*}{$\begin{array}{c}\text { Total } \\
\text { frequency }\end{array}$} \\
\cline { 2 - 3 } & Yes & no & 134 \\
\hline yes & 73 & 61 & 329 \\
\hline no & 165 & 164 & 463 \\
\hline $\begin{array}{l}\text { Total } \\
\text { frequency }\end{array}$ & 238 & 225 & \\
\hline
\end{tabular}

Table 1. Number of companies by success and search strategy. 
Methods or tools applied to reduce technical uncertainty

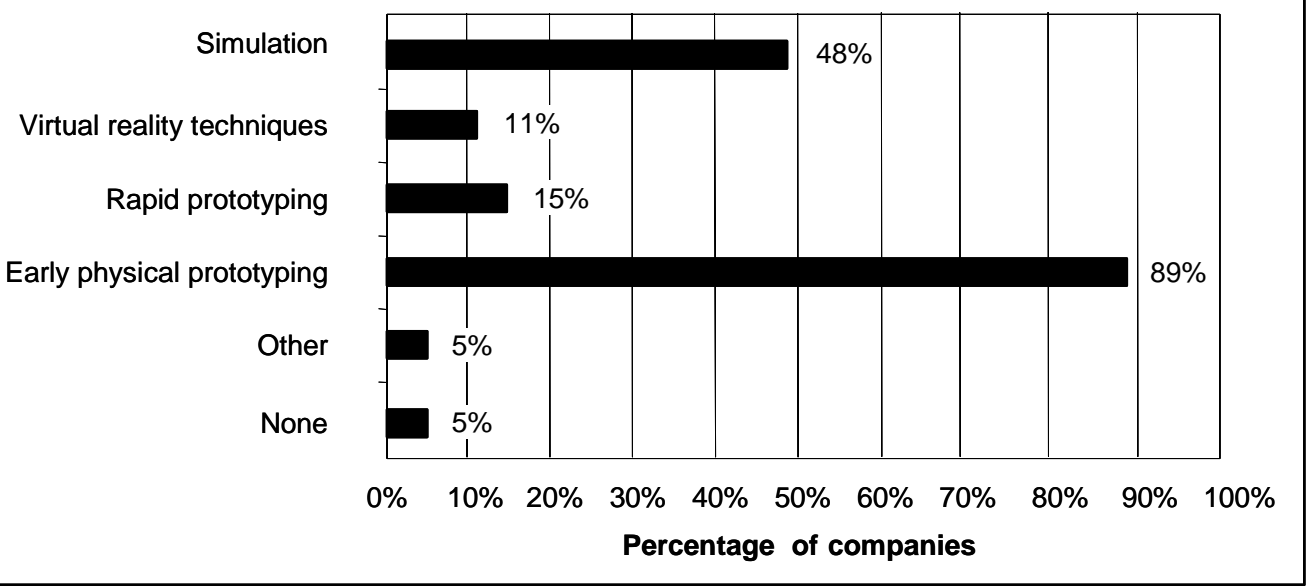

Figure 6. Methods or tools applied to reduce technical uncertainty.

Table 1 reveals that the majority of the respondents do not engage in a systematic search for new product ideas. In addition, performing a chi-square test of independence, the results also show that the hypothesis that there is no relationship between row and column frequencies cannot be refuted. Hence, the data does not support our proposition.

One possible explanation for this is that a systematic search for new product ideas is only the beginning of a NPD project. Many uncertainties still remain at this point, such as the question whether the ideas generated will pass the assessment step or be terminated there. Consequently, a systematic approach to searching for new product ideas may in itself not be influential enough to already have an effect on corporate success at such an early phase of the NPD process.

After generating a number of ideas, the next step, idea assessment, is necessary to decide on the execution of an idea or to select the most promising idea from alternatives. The importance of this step within the product development process is empirically supported by studies in Western countries as well as in Japan and other countries (Cooper and Kleinschmidt, 1986: 82; Cooper and Kleinschmidt, 1994: 25; Johne and Snelson, 1988: 119; Mishra, Kim and Lee, 1996: 540; Song and Parry, 1996: 431).

The risk in this step is twofold: On the one hand, the decision to continue with a project based on a bad idea entails further cost which leaves less available resources to other more promising projects. On the other hand, good ideas may not be recognized as such and promising ideas may be terminated with the consequence that the company may forgo a profitable business case.

Upper management support has frequently been found to contribute to successful NPD (Brown and Eisenhardt, 1995: 352). The involvement of upper management in the assessment of new product ideas may prove supportive to success inasmuch as upper management is likely to be more involved and offer greater support for ideas of which they approved during assessment in order to insure their success. Therefore, involvement of upper management in the assessment of new product ideas may result in support and championing for a project which has repeatedly been identified as contributing to new product success (Kim and Wilemon, 2002). Consequently, we propose that

P2: Upper management involvement in the assessment of new product ideas contributes positively to success.

\begin{tabular}{l|r|r|c}
\hline \multirow{2}{*}{$\begin{array}{c}\text { Involvement } \\
\text { of upper } \\
\text { management }\end{array}$} & yes & no & \multirow{2}{*}{$\begin{array}{c}\text { Total } \\
\text { frequency }\end{array}$} \\
\cline { 2 - 3 } & 189 & 169 & 368 \\
\hline Yes & 47 & 52 & 99 \\
\hline Sometimes & 2 & 3 & 5 \\
\hline No & 238 & 224 & 462 \\
\hline $\begin{array}{l}\text { Total } \\
\text { frequency }\end{array}$ & & & \\
\hline
\end{tabular}

Table 2. Number of companies by success and upper management involvement in the assessment of new product ideas.

Table 2 reveals that the majority of the companies involve upper management in the process of assessing new product ideas. However, performing a chi-square test of independence, we do not find support for our proposition in the data. This can be explained by the evidence, that almost every company in our sample involved upper management. Therefore, we can only compare companies which most of the time involve upper management to companies which sometimes involve upper management and not test our proposition.

Given that decisions frequently have to be made without having all of the relevant information at hand, idea assessment is accompanied by a high degree of uncertainty. The more radical the innovation project, the more difficult an early assessment of an idea becomes. In this context, interdisciplinary teams may be of value in order to account for as many facets and perspectives on a problem as possible.

Interfunctional integration has long been identified as a success factor for NPD (Cooper and Kleinschmidt, 1987: 171; Salomo, Gemünden and Billing, 2003: 167). Especially, cooperation between R\&D and marketing is regarded as vital to new product success (Souder, 1990: 15). Some authors suggest that the assessment of new 


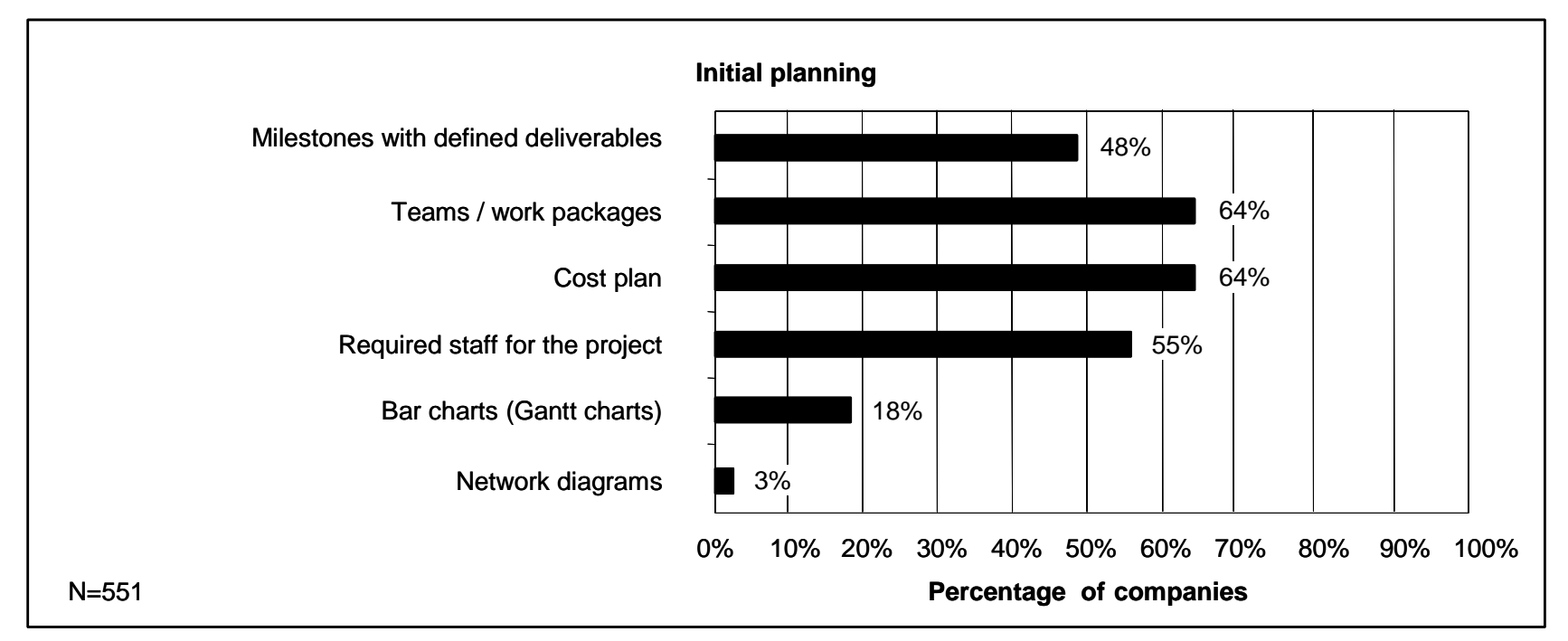

Figure 7. Market-related sources used to develop new product ideas.

product ideas provides a greater reduction of uncertainty if various corporate functions can contribute their specific knowledge and thereby allows for more successful products (Aggteleky and Bajina, 1992: 154-156; Song and Parry, 1997: 9). Hence, we suggest that

P3: New product idea assessment by interdisciplinary teams contributes positively to success.

\begin{tabular}{l|c|c|c}
\hline $\begin{array}{l}\text { Involvement } \\
\text { of inter- } \\
\text { disciplinary } \\
\text { teams }\end{array}$ & \multicolumn{2}{|c|}{ Success } & \\
\cline { 2 - 3 } & yes & no & $\begin{array}{c}\text { Total } \\
\text { frequency }\end{array}$ \\
\hline yes & 121 & 93 & 214 \\
\hline sometimes & 74 & 83 & 157 \\
\hline No & 43 & 49 & 92 \\
\hline $\begin{array}{l}\text { Total } \\
\text { frequency }\end{array}$ & 238 & 225 & 462 \\
\hline
\end{tabular}

Table 3. Number of companies by success and interdisciplinary teams in the assessment of new product ideas.

From Table 3, the calculated $\chi^{2}=4.209$, which has less than a $15 \%$ probability of occurring if the classifications were independent. Our suggestion that the assessment of new product ideas by interdisciplinary teams contributes to success therefore cannot be supported by the data.

After the assessment and selection of an idea, the concept has to be worked out in more detail. This includes the reduction of market uncertainty in order to arrive at a deeper understanding of the external environment. The target market has to be defined and customer requirements have to be integrated into the product concept, prior to development (Balbontin et al., 1999: 274; Cooper and Kleinschmidt, 1990: 26; Cooper and Kleinschmidt, 1994: 26; Khurana and Rosenthal, 1997: 113; Maidique and Zirger, 1984: 198; Song and Parry, 1996: 427).

One possible way is to extensively use customer or user information for developing the new product concept. This type of information can either be gathered by direct contact with customers or by relying on functions operating closely with client organizations such as after sales/customer service. Consequently, companies should maintain close and direct relationships with their customers. While it is frequently argued that it is more difficult to reduce market uncertainty in new markets as potential customers are often unable to articulate their needs or may not even be aware of them (Mullins and Sutherland, 1998: 228). Callahan and Lasry (2004: 116) argue that customer input is always important but for the case of very new products. Following this notion we suggest that

P4: Successful companies contact their customers more often to develop and evaluate new product ideas than unsuccessful companies.

\begin{tabular}{l|r|r|c}
\hline \multirow{2}{*}{$\begin{array}{c}\text { Customer } \\
\text { contact }\end{array}$} & \multicolumn{2}{|c|}{ Success } & \multirow{2}{*}{$\begin{array}{c}\text { Total } \\
\text { frequency }\end{array}$} \\
\cline { 2 - 3 } & yes & \multicolumn{1}{c|}{ no } & 249 \\
\hline very often & 144 & 105 & 186 \\
\hline Sometimes & 84 & 102 & 27 \\
\hline very seldom & 9 & 18 & 462 \\
\hline $\begin{array}{l}\text { Total } \\
\text { frequency }\end{array}$ & 237 & 225 & \\
\hline
\end{tabular}

Table 4. Number of companies by success and frequency of customer contact.

Table 4 reveals that the majority of the respondents contact their customers very often. In addition, the chi-square test of independence $\left(\chi^{2}=10.546\right)$ shows that there is only a less than $1 \%$ probability that the frequencies are independent. Hence, we find strong support for our proposition in the data.

Within the process of NPD, each corporate function should contribute according to its special strengths and abilities. The marketing department has been repeatedly identified as a source of valuable knowledge for the project team (Benkenstein, 1987; Griffin and Hauser, 1996; Cooper and Kleinschmidt, 1987). It is in close contact with a company's customers, and is more knowledgeable about their problems and needs than any other corporate function. It understands the "voice 
of the customer" and thereby allows for the development of products that correspond to market needs. Therefore, we suggest that

P5: Contact between Marketing and customers positively contributes to success.

Analogous to the description of the results in the former section, we perform this analysis only for the 435 companies which contact their customers at least sometimes to develop and evaluate new product ideas.

\begin{tabular}{|c|c|c|c|}
\hline \multirow{2}{*}{$\begin{array}{c}\text { Marketing } \\
\text { contacts } \\
\text { customers }\end{array}$} & \multicolumn{2}{|c|}{ Success } & \multirow[b]{2}{*}{$\begin{array}{c}\text { Total } \\
\text { frequency }\end{array}$} \\
\hline & yes & no & \\
\hline Yes & 126 & 87 & 213 \\
\hline No & 102 & 120 & 222 \\
\hline $\begin{array}{l}\text { Total } \\
\text { frequency }\end{array}$ & 228 & 207 & 435 \\
\hline
\end{tabular}

Table 5. Number of companies by success and department contacting customers.

From Table 5, the calculated $\chi^{2}=7.604$, which has less than a $1 \%$ probability of occurring if the classifications were independent. These data reveal strong support for our notion that the frequency of marketing contacting customers is higher for successful firms than for unsuccessful companies.

However, listening to one's customers and gathering information from them is not sufficient. In order to develop products which will be successful in the market place, the companies have to derive customer requirements from the information gathered and integrate these into the definition of their new product concepts. We therefore propose that

P6: Systematic integration of customer requirements into the definition of new product concepts contributes positively to success.

\begin{tabular}{l|r|r|c}
\hline \multirow{2}{*}{$\begin{array}{c}\text { Systematic } \\
\text { integration } \\
\text { of customer } \\
\text { requirements }\end{array}$} & \multicolumn{2}{|c|}{ Success } & \multirow{2}{*}{$\begin{array}{c}\text { Total } \\
\text { frequency }\end{array}$} \\
\hline yes & 89 & 46 & 135 \\
\hline sometimes & 109 & 122 & 231 \\
\hline no & 39 & 57 & 96 \\
\hline $\begin{array}{l}\text { Total } \\
\text { frequency }\end{array}$ & 237 & 225 & 462 \\
\hline
\end{tabular}

Table 6. Number of companies by success and systematic integration of customer requirements into new product concepts.

From Table 6, the calculated $\chi^{2}=17.503$, which has less than a $0.1 \%$ probability of occurring if the classifications were independent. Hence, we find strong support for our proposition in the data.

The final step then is to translate the customer requirements into technical specifications, which can be done using QFD, as was described above. The customer information is rephrased in a way that allows for the engineering of the product concept. Hence
P7: Companies systematically translating customer requirements into technical specifications are more successful than companies not doing so.

\begin{tabular}{|c|c|c|c|}
\hline \multirow{2}{*}{$\begin{array}{l}\text { Translation } \\
\text { of customer } \\
\text { requirements }\end{array}$} & \multicolumn{2}{|c|}{ Success } & \multirow[b]{2}{*}{$\begin{array}{c}\text { Total } \\
\text { frequency }\end{array}$} \\
\hline & yes & no & \\
\hline yes & 107 & 77 & 135 \\
\hline sometimes & 99 & 107 & 231 \\
\hline no & 31 & 40 & 96 \\
\hline $\begin{array}{l}\text { Total } \\
\text { frequency }\end{array}$ & 237 & 224 & 461 \\
\hline
\end{tabular}

Table 7. Number of companies by success and translation of customer requirements into technical specifications.

Table 7 reveals that the majority of the respondents at least sometimes translate customer requirements into technical specifications. In addition, the chi-square test of independence $\left(\chi^{2}=5.981\right)$ shows that there is a $5 \%$ probability that the frequencies are independent. Hence, we find support for our proposition in the data.

According to the "rational plan" research stream in NPD, “a project that is well planned, implemented, and appropriately supported will be a success” (Brown and Eisenhardt, 1995: 348). As has been stated above, planning of NPD projects has been repeatedly identified as a significant determinant of new product success in Western countries as well as in Japan (Thieme, Song and Shin, 2003; Song and Parry, 1996: 432; Balachandra and Friar, 1997: 279; Pinto and Slevin, 1988: 67; Maidique and Zirger, 1984: 198). On the other hand, it is argued that planning might not be beneficial under all circumstances, such as in a rapidly changing environment for example, and that NPD success in those cases rather depends on the company's ability to improvise (Benkenstein, 1987). However, as this second view only addresses more specific circumstances, we follow the first argument and propose:

P8: Companies systematically planning a project prior to its start are more successful as companies which do not systematically plan innovation projects.

\begin{tabular}{l|c|c|c}
\hline \multirow{2}{*}{$\begin{array}{c}\text { Systematic } \\
\text { planning } \\
\text { prior to start }\end{array}$} & yes & no & $\begin{array}{c}\text { Total } \\
\text { frequency }\end{array}$ \\
\cline { 2 - 3 } & 109 & 82 & 191 \\
\hline Yes & 101 & 122 & 223 \\
\hline Sometimes & 28 & 21 & 49 \\
\hline No & 238 & 225 & 463 \\
\hline $\begin{array}{l}\text { Total } \\
\text { frequency }\end{array}$ & & & \\
\hline
\end{tabular}

Table 8 . Number of companies by success and systematic initial planning.

As is evident from Table 8, there exists a relationship between the two frequencies. The chi-square test of independence shows that there is a less than $5 \%$ probability that the frequencies are 
independent. We therefore find support for our proposition in the data.

\section{Conclusions}

The companies in our sample engage in a variety of activities to generate new product ideas. In accordance with prior research (Herstatt et al., 2004: 20; Harryson, 1996: 26) we find that Japanese companies employ a number of different creativity techniques of which brainstorming is the most important.

As advocated by previous research (Cooper and Kleinschmidt, 1987: 171; Souder, 1990: 15; Aggteleky and Bajina, 1992: 154-156; Song and Parry, 1997: 9; Salomo, Gemünden and Billing, 2003: 167), the majority of the companies involve interdisciplinary teams and upper management in the assessment of new product ideas. However, our analysis cannot link these practices to corporate success.

The respondents use various sources of information to reduce uncertainties inherent in NPD. Customers represent the most prominent source of information for the companies followed by competitor analysis. Information from customers is not only gathered via direct contact. The companies also evaluate customer complaints and conduct surveys. It shows to be most beneficial, if marketing contacted customers.

We found strong support for our suggestion that frequent contact with customers is important to company success. However, this is not sufficient in itself: The gathered information and customer requirements need to be integrated into the product concept. This requires them to be translated into technical specifications. Both of these activities are more often carried out by successful companies than their unsuccessful competitors.

Finally a systematic approach to planning NPD projects is found to be positively related to corporate success.

Overall, we were able to support and extend the findings of Herstatt et al. (2004) with regard to Japanese management practices during the fuzzy front end of the innovation process.

\section{References}

Aggteleky, B. and Bajina, N. (1992) Projektplanung: ein Handbuch für Führungskräfte, München and Wien: Hanser

Baker, N.R., Green, S.G. and Bean, A.S. (1985) How management can influence the generation of ideas, Research Management, 28, 6, 35-42

Balachandra, R. and Friar, J.H. (1997) Factors for success in $R \& D$ projects and new product innovation: A contextual framework, IEEE Transactions on Engineering Management, 44, 3, 276-287

Balbontin, A., Yazdani, B., Cooper, R. and Souder, W.E. (1999) New product development success factors in American and British firms, International Journal of Technology Management, 17, 3, 259-280
Benkenstein, M. (1987) F\&E und Marketing: eine Untersuchung zur Leistungsfähigkeit von Koordinationskonzeptionen bei Innovationsentscheidungen, Wiesbaden: Gabler

Brown, S.L. and Eisenhardt, K.M. (1995) Product Development: Past Research, Present Findings, and Future Directions, Academy of Management Review, 20, 2, 343-378

Callahan, J. and Lasry, E. (2004) The importance of customer input in the development of very new products, $R \& D$ Management, 34, 2, 107-120

Clayton, M.J., Kunz, J.C. and Fischer, M.A. (1996) Rapid conceptual design evaluation using a virtual product model, Engineering Applications of Artificial Intelligence, 9, 4, 439-451

Cooper, R.G. and Kleinschmidt, E.J. (1986) An investigation into the new product process - steps, deficiencies, and impact, Journal of Product Innovation Management, 3, 3, 71-85

Cooper, R.G. and Kleinschmidt, E.J. (1987) New Products: What Separates Winners from Losers?, Journal of Product Innovation Management, 4, 3, 169-184

Cooper, R. C. and Kleinschmidt, E. J. (1990) New products: The key factors in success, American Marketing Association, United States 1990

Cooper, R.C. and Kleinschmidt, E.J. (1994) Screening new products for potential winners, Institute of Electrical and Electronics Engineers IEEE engineering management review, 22, 4, 24-30

Geschka, H. (1992) Creativity techniques in product planning and development: a view from West Germany. In Parnes, S.J. (ed.), Source book of creative problem-solving, Buffalo: Creative Education Foundation Press, pp. 282-298

Griffin, A. and Hauser, J.R. (1993) The voice of the customer, Marketing Science, 12, 1 1-27

Griffin, A. and Hauser, J.R. (1996) Integrating R\&D and marketing: a review and analysis of the literature, Journal of Product Innovation Management, 13, 3, 191-215

Harryson, S. (1996) Improving R\&D performance through networking - lessons from Canon and Sony, Arthur D. Little - Prism, Fourth Quarter 1996

Herstatt, C. (2002): Search fields for radical innovations, International Journal of Entrepreneurship and Innovation Management, 2, 1, 71-95

Herstatt, C., Verworn, B. (2004) The Fuzzy Front End of Innovation. In: EITIM (ed.) Bringing Technology and Innovation into the Boardroom, Houndmills and New York: Palgrave MacMillan, pp. 347-373

Herstatt, C., Verworn, B. and Nagahira, A. (2004) Reducing project related uncertainty in the "fuzzy front end" of innovation - A comparison of German and Japanese product innovation projects, International Journal of Product Development, 1, 1, in print

Johne, F.A. and Snelson, P.A. (1988) Success factors in product innovation - a selective review of the literature, Journal of Product Innovation Management, 5, 2, 114-128

Khurana, A. and Rosenthal, S. R. (1997) Integrating the fuzzy front end of new product development, Sloan Management Review, 38, 2, 103-120 
Khurana, A. and Rosenthal, S. R. (1998) Towards holistic "front ends" in new product development, Journal of Product Innovation Management, 15, 1, 57-74

Kim, J. and Wilemon, D. (2002) Focusing the fuzzy front-end in new product development, $R \& D$ Management, 32, 4, 269-279

Koen, P., Ajamian, G., Burkart, R., Clamen, A. et al. (2001) Providing clarity and a common language to the "fuzzy front end", Research Technology Management, 44, 2, 46-55

Maidique, M.A. and Zirger, B.J. (1984) A study of success and failure in product innovation, IEEE Transactions on Engineering Management, EM-31, 4, 192-203

Mishra, S., Kim, D. and Lee, D.H. (1996) Factors affecting new product success: cross-country comparison, Journal of Product Innovation Management, 13, 6, 530-550

Mullins, J.W. and Sutherland, D.J. (1998) New product development in rapidly changing markets: an exploratory study, Journal of Product Innovation Management, 15, 3, 224-236

Pinto, J.K. and Slevin, D.P. (1988) Critical success factors across the project life cycle, Project Management Journal, 19, 3, 67-75

Rochford, L. (1991) Generating and screening new product ideas, Industrial Marketing Management, 20, 4, 287-296

Rubinstein, A.H. (1994) At the front end of the R\&D/innovation process - idea development and entrepreneurship, International Journal of Technology Management, 9, 5, 6, 7, 652-677

Salomo, S., Gemünden, H.G. and Billing, F. (2003) Dynamisches Schnittstellenmanagement radikaler Innvoationsvorhaben. In: Herstatt, C. and Verworn, B. (eds), Management der frühen Innovationsphasen: Grundlagen, Methoden, Neue Ansätze, Wiesbaden: Gabler, pp. 161-194

Song, X.M. and Parry, M.E. (1996) What separates Japanese new product winners from losers, Journal of Product Innovation Management, 13, 5, 422-439

Song, X.M. and Parry, M.E. (1997) A cross-national comparative study on new product development processes: Japan and the United States, Journal of Marketing, 61, 2, 1-18

Souder, W.E. (1990) Managing the Interface between $\mathrm{R} \& \mathrm{D}$ and Marketing, Advances in Telecommunications Management, Volume 1, pp. 15-33

Thieme, J.R., Song, X.M. and Shin G.C. (2003) Project Management Characteristics and New Product Survival, Journal of Product Innovation Management, 20, 2, 104-119

Vergant, R (1997) Leveraging on systematic learning to manage the early phases of product innovation projects, R\&D Management, 27, 4, 377-392

Watts, T., Swann, P.G.M. and Pandit, N.R. (1998) Virtual reality and innovation potential, Business Strategy Review, 9, 3, 45-54

Yoshida, P.G. (2002) Japan's R\&D remains strong as economy struggles to turn corner, Research Technology Management, 45, 6, 2-4

Zhang, Q. and Doll, W.J. (2001) The fuzzy front end and success of new product development: a causal model, European Journal of Innovation Management, 4, 2, 95-112 